\title{
Molecular sexing of unusually large numbers of Spheniscus magellanicus (Spheniscidae) washed ashore along the Brazilian coast in 2008
}

\author{
E.C. Reis ${ }^{1}$, R.M. Aires ${ }^{1}$, J.F. Moura ${ }^{2}$, C.A.R. Matias ${ }^{2}$, M. Tavares ${ }^{3,4}$, \\ P.H. Ott ${ }^{4,5}$, S. Siciliano ${ }^{2}$ and G. Lôbo-Hajdu ${ }^{1}$ \\ ${ }^{1}$ Laboratório de Genética Marinha (LGMar), Departamento de Genética, \\ Universidade do Estado do Rio de Janeiro, Rio de Janeiro, RJ, Brasil \\ ${ }^{2}$ Departamento de Endemias, \\ Grupo de Estudos de Mamíferos Marinhos da Região dos Lagos, \\ Escola Nacional de Saúde Pública, Rio de Janeiro, RJ, Brasil \\ ${ }^{3}$ Centro de Estudos Costeiros, Limnológicos e Marinhos, \\ Universidade Federal do Rio Grande do Sul, Imbé, RS, Brasil \\ ${ }^{4}$ Grupo de Estudos de Mamíferos Aquáticos do Rio Grande do Sul, \\ Porto Alegre, RS, Brasil \\ ${ }^{5}$ Laboratório de Biologia da Conservação de Aves e Mamíferos Aquáticos, \\ Universidade Estadual do Rio Grande do Sul, Cidreira, RS, Brasil \\ Corresponding author: E.C. Reis \\ E-mail: est.cardinot@gmail.com
}

Genet. Mol. Res. 10 (4): 3731-3737 (2011)

Received May 18, 2011

Accepted October 24, 2011

Published December 5, 2011

DOI http://dx.doi.org/10.4238/2011.December.5.7

\begin{abstract}
There have been few studies on Magellanic penguins (Spheniscus magellanicus). In 2008, these penguins washed ashore along the Brazilian coast in unusually high numbers, some reaching as far as northeast Brazil. As Magellanic penguins show little sexual dimorphism, sex determination by morphological features is not accurate. Here, we tested a molecular procedure for sexing specimens of S. magellanicus washed ashore along the coasts of Sergipe, Rio
\end{abstract}


de Janeiro and Rio Grande do Sul in 2008, comparing the sex ratio between these localities. Tissue samples were collected from 135 dead, beached specimens. We carried out total genomic DNA extraction and CHD-Z/CHD-W gene amplification by PCR using P2 and P8 primers. Amplicons were separated by $12 \%$ acrylamide gel electrophoresis. We found a greater proportion of females $(70 \%)$. Sex could be determined because females have two intronic regions of CHD gene of different size in the sex chromosomes, visualized as two bands on the gel (380 and 400 bp approximately), while males have only one (400 bp). Therefore, this method proved to be effective and sensitive for sex determination of $S$. magellanicus individuals. Data on sex ratios are useful for understanding the dynamics and ecology of Magellanic penguin populations.

Key words: DNA sexing; Sex determination; Sex chromosomes; CHD introns; Magellanic penguin

\section{INTRODUCTION}

Morphological identification of sex in birds can often be difficult, and thus, the innovation of molecular sexing techniques is crucial for investigating many subjects in ecology and evolution (Ellegren and Sheldon, 1997; Dubiec and Zagalska-Neubauer, 2006; Shizuka and Lyon, 2008). The molecular methods most frequently used for sexing birds are based on the size differences between introns of the CHD gene on the $\mathrm{Z}$ and $\mathrm{W}$ sex chromosomes (Griffiths et al., 1998; Fridolfsson and Ellegren, 1999). Heterogametic females (ZW) are expected to have two differentsized introns, while homogametic males (ZZ) should show only one (Shizuka and Lyon, 2008).

The Magellanic penguin, Spheniscus magellanicus (Forster, 1781), is the most abundant species of penguins in South America, with breeding colonies along the Pacific and Atlantic coasts (Chile and Argentina), including the Falkland Islands (Scolaro, 1987a; Stokes and Boersma, 1999; Yorio et al., 2001). On the Atlantic coast, the species disperses northward after the breeding season, usually reaching the southern coast of Brazil (Sick, 1997; García-Borboroglu et al., 2006). S. magellanicus is the most abundant bird species stranding annually along the Brazilian coast, mainly during austral winter and spring (Sick, 1997; Petry et al., 2004; Vega et al., 2009; Mäder et al., 2010). In 2008, Magellanic penguins reached the Brazilian coast at an unusual frequency, including reports of stranded specimens in Northeast Brazil, an extremely rare event (García-Borboroglu et al., 2010).

This species shows little sexual dimorphism (Martínez, 1992; Agnew and Kerry, 1995) and is generally sexed using biometric data (Amat et al., 1993; Renner et al., 1998), copulation observation (Scolaro et al., 1990), cloacal examination (Renner et al., 1998; Renner and Davies, 1999), or dissection (Scolaro et al., 1983, 1987b). However, these approaches present limitations, and just molecular procedures have proved to be useful for positive sexing of individuals at any life stage (Bertellotti et al., 2002). Although some genetic procedures have been applied to penguin species (Dubach, 1996; Costantini et al., 2008; Lee et al., 2010), these techniques were applied just once for Magellanic penguins (see Bertellotti et al., 2002).

In the present study, we tested a molecular procedure for sex determination of 135 samples of dead S. magellanicus stranded along the Sergipe, Rio de Janeiro and Rio Grande do Sul coasts in 2008, comparing the sex ratio between these localities. 


\section{MATERIAL AND METHODS}

GEMM-Lagos (Grupo de Estudos de Mamíferos Marinhos da Região dos Lagos) staff and collaborators made regular beach monitoring along the Brazilian coast in 2008, recovering stranded marine mammals, sea turtles and seabirds (Figure 1). A total of 135 samples were collected from dead specimens of $S$. magellanicus found in Sergipe $(\mathrm{N}=12)$, Rio de Janeiro $(\mathrm{N}=$ $106)$ and Rio Grande do Sul $(\mathrm{N}=17)$. Most of the individuals were immature ( 75 specimens from a total of 79 classified according to life stage), since they lacked the clearly defined banding of the adults (Sick, 1997). Samples of liver and/or breast muscle were collected and stored in $70 \%$ Ethanol. The sex of some fresh individuals was determined by dissection $(\mathrm{N}=10$, six females and four males), and they were used as positive controls for polymerase chain reaction (PCR).

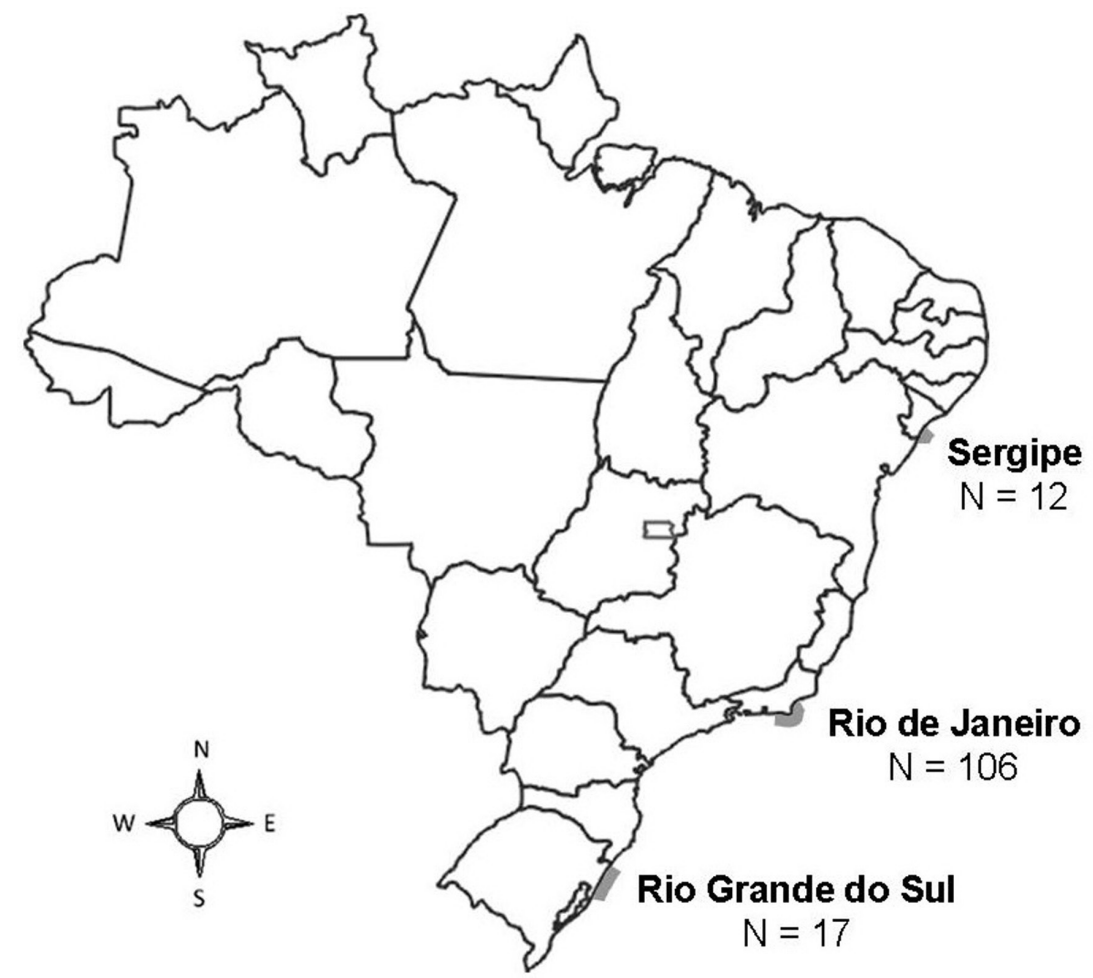

Figure 1. Collection sites and number $(\mathrm{N})$ of stranded Magellanic penguin (Spheniscus magellanicus) samples gathered along the Brazilian coast in 2008.

Total genomic DNA extraction was carried out according to a modified protocol from Damato and Corach (1996), using a lysis buffer containing 2\% cetyl trimethyl ammonium bromide (CTAB), $100 \mathrm{mM}$ Tris-HCl pH 8.0, $20 \mathrm{mM}$ EDTA and 1.4 M NaCl. CHD-Z and CHD-W introns were amplified by PCR using P2 (5'-TCT GCA TCG CTA AAT CCT TT-3') and P8 (5'-CTC CCA AGG ATG AGR AAY TG-3') primers (Griffiths et al., 1998). Each 10- $\mu \mathrm{L}$ reaction mixture contained about $10 \mathrm{ng}$ genomic DNA, $1 \mu \mathrm{M}$ of each primer and $0.25 \mathrm{U}$ Taq DNA polymerase (Biotools), also including $2 \mathrm{mM} \mathrm{MgCl}_{2}$ and $200 \mu \mathrm{M}$ dNTPs. The PCR amplifica- 
tion profile was $94^{\circ} \mathrm{C}$ for $2 \mathrm{~min}$, followed by 40 cycles of $94^{\circ} \mathrm{C}$ for $45 \mathrm{~s}, 50^{\circ} \mathrm{C}$ for $45 \mathrm{~s}, 72^{\circ} \mathrm{C}$ for $45 \mathrm{~s}$, and a final extension step of $72^{\circ} \mathrm{C}$ for $5 \mathrm{~min}$. All reactions were carried out including positive and negative controls (template-free reactions) in order to test for contamination and to assure the fidelity of the PCR amplifications.

Each $10 \mu \mathrm{L}$ of amplified fragment were mixed with $2 \mu \mathrm{L}$ of loading buffer ( $30 \%$ glycerol, $0.25 \%$ bromophenol blue and $0.25 \%$ xylene cyanol). This mixture was loaded on a nondenaturing 12\% acrylamide gel (99:1 acrylamide:bis-acrylamide) (Sambrook et al., 1989), and run for $3 \mathrm{~h}$ at $140 \mathrm{~V}$. Afterwards, the gels were stained with silver nitrate according to Bassam et al. (1991) and dried, and the image was digitized.

After sexing S. magellanicus from Sergipe, Rio de Janeiro and Rio Grande do Sul, a chi-square test was used to compare the sex ratio in these three sampled sites.

\section{RESULTS}

CHD-W and CHD-Z introns of Magellanic penguins showed about $400 \mathrm{bp}$ and 380 bp, respectively, when amplified with P2 and P8 primers (Figure 2). Such small differences between CHD-W and CHD-Z amplified fragments (20 bp) required runs on 12\% acrylamide gels to better separate the bands, since acrylamide provides better resolution compared to agarose (Dubiec and Zagalska-Neubauer, 2006). However, similar fragment lengths were found by Bertellotti et al. (2002), separating fragments on 3\% agarose gel. In the present study, the ten individuals (six females and four males) of S. magellanicus used as controls for PCR showed $100 \%$ correlation between molecular and morphological sex determination.

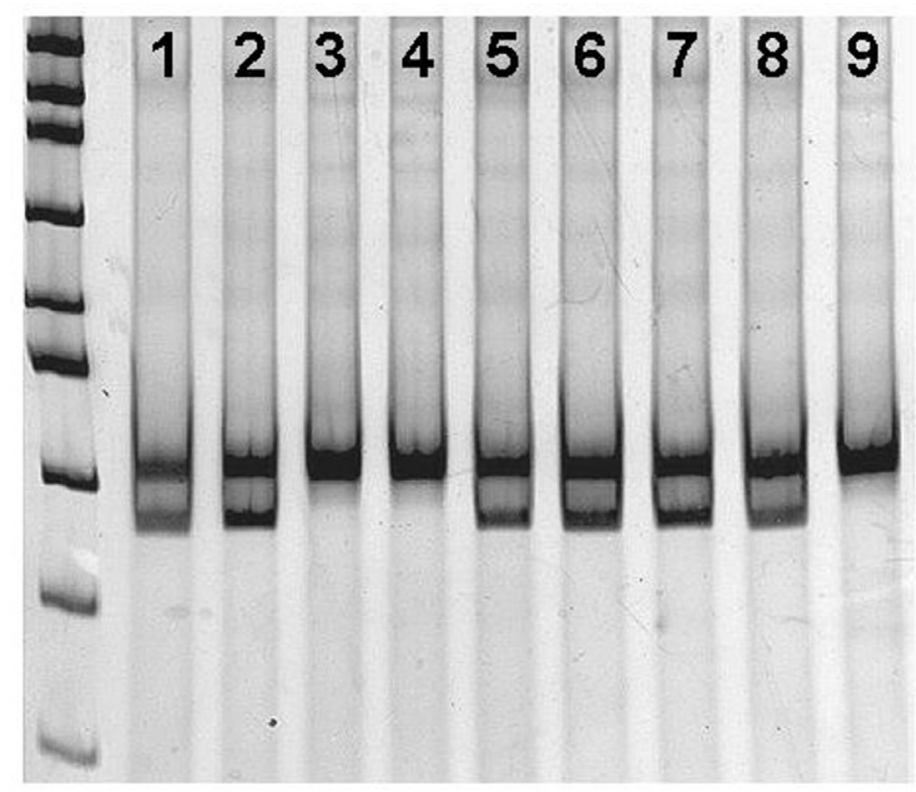

Figure 2. Amplicons of CHD-Z and CHD-W introns of Magellanic penguins (Spheniscus magellanicus) separated by $12 \%$ acrylamide gel electrophoresis and stained with silver nitrate. Lanes 1,2 and $5-8=$ heterogametic females (ZW), lanes 3,4 and $9=$ homogametic males (ZZ). At the left, Gene Ruler ${ }^{\mathrm{TM}} 100$ bp DNA ladder (Fermentas - Life Sciences) with the following visible fragments in base pairs: 1031, 900, 800, 700, 600, 500, 400, 300 and 200. 
Five individuals (three from Rio de Janeiro and two from Rio Grande do Sul) could not be sexed due to their advanced state of decomposition. Sex determination of 130 samples of $S$. magellanicus stranded along the Brazilian coast in 2008 indicated a greater proportion of females (70\%). Magellanic penguins from Rio de Janeiro $(\mathrm{N}=103)$ showed $70 \%$ females, more than double the number of males (30\%). Sergipe and Rio Grande do Sul, even with smaller sample sizes $(\mathrm{N}=12$ and $\mathrm{N}=15$, respectively), showed similar ratios (Figure 3 ). A chi-square test demonstrated that there were no differences in $S$. magellanicus sex ratio between Sergipe, Rio de Janeiro and Rio Grande do $\operatorname{Sul}\left(\chi^{2}=1.62 ; \mathrm{df}=2 ; \mathrm{P} \approx 0.5\right)$.

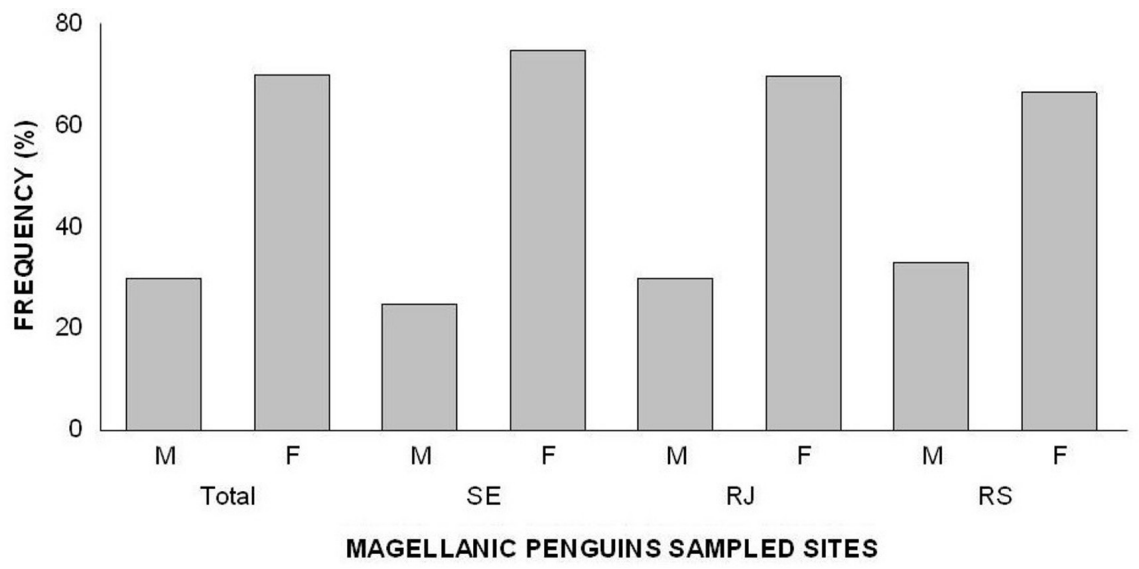

Figure 3. Sex ratio of Magellanic penguins (Spheniscus magellanicus) stranded along the Brazilian coast in 2008. $\mathrm{M}=$ male; $\mathrm{F}=$ female; $\mathrm{SE}=$ Sergipe $\mathrm{RJ}=$ Rio de Janeiro, and $\mathrm{RS}=$ Rio Grande do Sul.

\section{DISCUSSION}

The molecular method used in the present study proved to be effective and sensitive for sex determination of S. magellanicus individuals. Heterogametic females (ZW) could be distinguished on polyacrylamide gel electrophoresis (PAGE) by two bands, while homogametic males (ZZ) showed only one. Bertellotti et al. (2002) correlated molecular and biometric approaches, and concluded that only molecular procedures proved appropriate for accurately sexing both adults and chicks of Magellanic penguins. Dubiec and Zagalska-Neubauer (2006) still highlighted that sex determination based on the amplification of CHD genes is the most rapid, inexpensive and reliable technique. Nonetheless, some studies have pointed to the existence of polymorphisms in CHD-Z introns of several bird species, which complicates the determination of sex since heterozygote males will also have two different-sized introns (Dawson et al., 2001; Lee et al., 2002; Robertson and Gemmell, 2006). It is still unknown how many species possess polymorphism in the CHD-Z gene, which will only be detected with adequate sampling of known sexed individuals (Shizuka and Lyon, 2008).

Our results indicated a greater proportion of females, which could be explained if colonies of Magellanic penguins have a female-biased sex ratio. However, in many species of penguins, the sex ratio is markedly biased towards males (Williams, 1996). Another hypothesis to explain this greater proportion of stranded females along the Brazilian coast is that dispersal forays of females could begin earlier in their lives, consequently increasing female mortality. As females begin breeding before males (Scolaro, 1987a), it is also possible that females also start their migration first. In 
fact, in the present study, $95 \%$ of the specimens sampled that were classified according to life stage were juveniles. The predominance of juveniles of $S$. magellanicus along the Brazilian coast was also noticed in previous studies (e.g., García-Borboroglu et al., 2006; 2010; Mäder et al., 2010). Satellite telemetry studies have already demonstrated extensive foraging ranges among Magellanic penguins (Stokes and Boersma, 1999; Pütz et al., 2000; Boersma et al., 2009). By mid-April, all adults have completed their molt and start their annual pelagic migration, with many individuals reaching the Southern coast of Brazil (Scolaro, 1987a; García-Borboroglu et al., 2010).

Despite being probably by far the most abundant bird species stranded along the Brazilian coast, Magellanic penguins are still poorly studied. Hence, the continuity of this kind of study and related ones is very important. Data on sex determination will be important for better understanding the dynamics and ecology of Magellanic penguin populations, including sex ratio development, sexual selection, parental care strategies, migration, demography and conservation (Shizuka and Lyon, 2008).

\section{ACKNOWLEDGMENTS}

We thank GEMARS (Grupo de Estudos de Mamíferos Aquáticos do Rio Grande do Sul), CECLIMAR/IB/UFRGS (Centro de Estudos Costeiros, Limnológicos e Marinhos, Instituto de Biociências, Universidade Federal do Rio Grande do Sul), GEMM-Lagos (Grupo de Estudos de Mamíferos Marinhos da Região dos Lagos), NUPEM/UFRJ (Núcleo em Ecologia e Desenvolvimento Sócio-Ambiental de Macaé da Universidade Federal do Rio de Janeiro), Parque dos Pássaros/Prefeitura de Rio das Ostras, Jardim Zoológico/Prefeitura da Cidade do Rio de Janeiro, Universidade Estácio de Sá, and V.V.B. Silveira for the support in the collection of samples in Sergipe, Rio de Janeiro and Rio Grande do Sul. E.C. Reis is supported by Fundação Carlos Chagas Filho de Amparo à Pesquisa do Estado do Rio de Janeiro - FAPERJ (Grant \#E-26/100.861/2010) and is a PhD student of PPGEE-UERJ (Programa de Pós-Graduação em Ecologia e Evolução, Universidade do Estado do Rio de Janeiro). R.M. Aires is supported by FAPERJ (Grant \#E-26/102.171/2010). J.F. Moura is supported by Fundação Oswaldo Cruz (FIOCRUZ). P.H. Ott is supported by Conselho Nacional de Desenvolvimento Científico e Tecnológico - CNPq (Grant \#572180/2008-0). S. Siciliano is supported by CNPq. G. Lôbo-Hajdu is supported by FAPERJ (Grant \#E-26/110.260/2010). We are grateful to CENPES/PETROBRAS for managing the "Habitats Project - Campos Basin Environmental Heterogeneity", which included this study.

\section{REFERENCES}

Agnew DJ and Kerry KR (1995). Sexual Dimorphism in Penguins. In: The Penguins (Normar PNI and Reilly P, eds.). Beatty and Sons, Surrey, 299-318.

Amat JA, Viñuela J and Ferrer M (1993). Sexing chinstrap penguins (Pygoscelis antarctica) by morphological measurements. Colon. Waterbird. 16: 213-215.

Bassam BJ, Caetano-Anolles G and Gresshoff PM (1991). Fast and sensitive silver staining of DNA in polyacrylamide gels. Anal. Biochem. 196: 80-83.

Bertellotti M, Tella JL, Godoy JA, Blanco G, et al. (2002). Determining sex of Magellanic Penguins using molecular procedures and discriminant functions. Waterbirds 25: 479-484.

Boersma PD, Rebstock GA, Frere E and Moore SE (2009). Following the fish: penguins and productivity in the South Atlantic. Ecol. Monog. 79: 59-76.

Costantini V, Guaricci AC, Laricchiuta P, Rausa F, et al. (2008). DNA sexing in Humboldt Penguins (Spheniscus humboldti) from feather samples. Anim. Reprod. Sci. 106: 162-167.

Damato ME and Corach D (1996). Genetic diversity of populations of the freshwater shrimp Macrobrachium borelli

Genetics and Molecular Research 10 (4): 3731-3737 (2011)

CFUNPEC-RP www.funpecrp.com.br 
(Cardidea, Palaemonidae) evaluated by RAPD analysis. J. Crust. Biol. 16: 650-655.

Dawson DA, Darby S, Hunter FM, Krupa AP, et al. (2001). A critique of avian CHD-based molecular sexing protocols illustrated by a Z-chromosome polymorphism detected in auklets. Mol. Ecol. Notes 1: 201-204.

Dubach J (1996). Gender determination in captive and wild species of penguins. Penguin Conserv. 9: 14-15.

Dubiec A and Zagalska-Neubauer M (2006). Molecular techniques for sex identification in birds. Biol. Lett. 43: 3-12.

Ellegren H and Sheldon BC (1997). New tools for sex identification and the study of sex allocation in birds. Trends Ecol. Evol. 12: 255-259.

Fridolfsson AK and Ellegren H (1999). A simple and universal method for molecular sexing of non-ratite birds. J. Avian Biol. 30: 116-121.

García-Borboroglu P, Boersma PD, Ruoppolo V, Reyes L, et al. (2006). Chronic oil pollution harms Magellanic penguins in the southwest Atlantic. Mar. Pollut. Bull. 52: 193-198.

Garcia-Borboroglu P, Boersma PD, Ruoppolo V, Pinho-da-Silva-Filho R, et al. (2010). Magellanic penguin mortality in 2008 along the SW Atlantic coast. Mar. Pollut. Bull. 60: 1652-1657.

Griffiths R, Double MC, Orr K and Dawson RJ (1998). A DNA test to sex most birds. Mol. Ecol. 7: 1071-1075.

Lee JC, Tsai LC, Hwa PY, Chan CL, et al. (2010). A novel strategy for avian species and gender identification using the CHD gene. Mol. Cell Probes 24: 27-31.

Lee PL, Brain PF, Forman DW, Bradbury RB, et al. (2002). Sex and death: CHD1Z associated with high mortality in moorhens. Evolution 56: 2548-2553.

Martínez I (1992). Family Spheniscidae (Penguins). In: Handbook of the Birds of the World, Vol. 1. (Del Hoyo J, Elliott A and Sargatal J, eds.). Lynx Editions, Barcelona, 140-172.

Mäder A, Sander M and Casa G Jr (2010). Ciclo sazonal de mortalidade do pinguim-de-magalhães, Spheniscus magellanicus influenciado por fatores antrópicos e climáticos na costa do Rio Grande do Sul, Brasil. Rev. Bras. Ornitol. 18: 228-233.

Petry MV, Fonseca VS and Jost AH (2004). Registro de Pinguins de Magalhães (Spheniscus magellanicus) mortos no Rio Grande do Sul. Acta Biol. Leopoldensia 26: 139-144.

Pütz K, Ingham RJ and Smith JG (2000). Satellite tracking of the winter migration of Magellanic Penguins Spheniscus magellanicus breeding in the Falkland Islands. Ibis 142: 614-622.

Renner M and Davis LS (1999). Sexing Little Penguins Eudyptula minor from Cook Strait, New Zealand, using discriminant function analysis. Ети 99: 74-79.

Renner M, Valencia J, Davis LS, Saez D, et al. (1998). Sexing of adult Gentoo Penguins in Antarctica using morphometrics. Colon. Waterbird. 21: 444-449.

Robertson BC and Gemmell NJ (2006). PCR-based sexing in conservation biology: wrong answers from an accurate methodology? Conserv. Genet. 7: 267-271.

Sambrook J, Fritsch EF and Maniatis T (1989). Molecular Cloning: A Laboratory Manual. 2nd edn. Cold Spring Harbor, New York.

Scolaro JA (1987a). A model life table for Magellanic penguins (Spheniscus magellanicus) at Punta Tombo, Argentina. J. Field Ornithol. 58: 432-441.

Scolaro JA (1987b). Sexing fledglings and yearlings of Magellanic Penguins by discriminant analysis of morphometric measurements. Colon. Waterbird. 10: 50-54.

Scolaro JA, Hall MA and Ximénez IM (1983). The Magellanic Penguin (Spheniscus magellanicus): Sexing adults by discriminant analysis of morphometric characters. Auk 100: 221-224.

Scolaro JA, Stanganelli ZB, Gallelli H and Vergani DF (1990). Sexing of Adult Adélie Penguins by Discriminant Analysis of Morphometric Measurements. In: Selected Scientific Papers of the Scientific Committee of CCAMLR. Hobart, 543-549.

Shizuka D and Lyon BE (2008). Improving the reliability of molecular sexing of birds using a W-specific marker. Mol. Ecol. Res. 8: 1249-1253.

Sick H (1997). Ornitologia Brasileira. Nova Fronteira, Rio de Janeiro.

Stokes DL and Boersma PD (1999). Where breeding Magellanic penguins Spheniscus magellanicus forage: satellite telemetry results and their implications for penguin conservation. Mar. Ornithol. 27: 59-65.

Vega CM, Siciliano S, Barrocas PR, Hacon SS, et al. (2010). Levels of cadmium, mercury, and lead in Magellanic penguins (Spheniscus magellanicus) stranded on the Brazilian coast. Arch. Environ. Contam. Toxicol. 58: 460-468.

Williams TD (1996). Mate Fidelity in Penguins. In: Partnerships in Birds: The Study of Monogamy. (Black JM, ed.). Oxford University Press Inc., New York, 268-285.

Yorio P, García P, Potti J and Moreno J (2001). Breeding biology of Magellanic Penguins Spheniscus magellanicus at Golfo San Jorge, Patagonia, Argentina. Mar. Ornithol. 29: 75-79. 